\title{
Razvoj panurotelijalnog karcinoma nakon transplantacije bubrega u pacijenta s endemskom nefropatijom
}

\section{The development of panurothelial carcinoma after kidney transplantation in patient with endemic nephropathy}

\author{
Ante Jakšići ${ }^{1 *}$, Josip Španjol ${ }^{1,2}$, Romano Oguići, ${ }^{1,2}$, Antun Grškovići ${ }^{1}$, Mauro Materljan ${ }^{1}$, \\ Monika Posavac ${ }^{2}$, Ivan Bubić, ${ }^{2,3}$, Dean Markić1,
}

${ }^{1}$ Klinika za urologiju, Klinički bolnički centar Rijeka, Rijeka, Hrvatska

${ }^{2}$ Medicinski fakultet, Sveučilište u Rijeci, Rijeka, Hrvatska

${ }^{3}$ Zavod za nefrologiju, dijalizu i transplantaciju bubrega, Klinika za internu medicinu, Klinički bolnički centar Rijeka, Rijeka, Hrvatska

\section{"Dopisni autor:}

Ante Jakšić, dr. med.

Klinika za urologiju, Klinički bolnički centar Rijeka, Tome Strižića 3, 51000 Rijeka

E-mail: antejaki5@gmail.com
Sažetak. Cilj: Endemska nefropatija (EN) je kronična bubrežna bolest koja nastaje zbog dugotrajnog izlaganja aristolohičnoj kiselini. EN je povezan $s$ razvojem terminalnog stadija bubrežne insuficijencije, ali i s razvojem karcinoma urotela, poglavito gornjeg dijela mokraćnoga sustava. U radu ćemo prikazati pacijenticu s endemskom nefropatijom, u koje se nakon presađivanja bubrega razvio panurotelijalni karcinom. Prikaz slučaja: U 76-godišnje pacijentice s EN-om je 2013. godine učinjena uspješna kadaverična transplantacija bubrega. Nakon transplantacije otkriven joj je površinski karcinom mokraćnoga mjehura koji je više puta liječen transuretralnim putem. Zbog pojave karcinoma u gornjem dijelu mokraćnoga sustava učinjena joj je i obostrana nefroureterektomija. Unatoč promjeni imunosupresivne terapije i kirurškom liječenju razvila se metastatska bolest uz letalni ishod tri godine po transplantaciji uz funkcionirajući presadak. Zaključak: U pacijenata s EN-om može doći do razvoja panurotelijalne bolesti, a posebno su ugroženi pacijenti u kojih je učinjena transplantacija bubrega. $U$ ove skupine pacijenata vrlo je važna prijetransplantacijska obrada, kao i praćenje nakon transplantacije bubrega.

Ključne riječi: bubrežna insuficijencija; endemska nefropatija; nefroureterektomija; transplantacija bubrega

\begin{abstract}
Aim: Endemic nephropathy (EN) is a chronic kidney disease caused by long-lasting exposure to aristolochic acid. EN is linked to the development of end-stage renal disease but also with the development of urothelial carcinoma, especially upper urinary tract carcinoma. We present a rare case of patient with EN who developed panurothelial cancer after kidney transplantation. Case report: In a 76-year-old woman with EN, a successful kidney transplantation was performed in 2013. After the transplantation, superficial bladder cancer was diagnosed and therefore treated with transurethral resection a few times. Later on, carcinoma of the upper urinary tract was also diagnosed so the bilateral nephroureterectomy was performed. Despite modified immunosuppression and surgical treatment, the metastatic disease was developed and the patient died three years after the transplantation, with the graft still being functional. Conclusion: Patients with EN have a higher risk of developing panurothelial carcinoma. Special attention must be given to EN patients who had kidney transplantation. In this group of patients, special consideration must be emphasized on pretransplant evaluation and follow-up after kidney transplantation.
\end{abstract}

Key words: endemic nephropathy; kidney transplantation; nephroureterectomy; renal insufficiency 


\section{UVOD}

Endemska nefropatija (EN) je kronična tubulointersticijska bolest bubrega karakterizirana asimptomatskim početkom i postupnim napredovanjem prema kroničnom zatajenju bubrega ${ }^{1}$. Od endemske nefropatije najčešće obolijevaju žitelji ruralnih područja dolina velikih pritoka rijeke Dunava u jugoistočnoj Europi, uključujući i Hrvatsku. U Republici Hrvatskoj ovom bolešću zahvaćeno je četrnaest sela pokraj Slavonskog Broda uz rijeku Savu. Prevalencija oboljelih je oko $5 \%$, a broj suspektnih na bolest oscilira između $10-15 \%$. Od EN-a češće obolijevaju žene, dok djeca nisu zahvaćena ${ }^{1}$.

Istraživanja su pokazala kako je glavni uzrok ove specifične bolesti aristolohična kiselina, otrovni alkaloid iz biljke vučje stope (lat. Aristolochia clematitis). Aristolohična kiselina ima dokazani kancerogeni učinak u ljudi ${ }^{1}$. U EN-a zahvaćena su dva ciljna tkiva: stanice proksimalnog tubula bubrega te stanice prijelaznoga epitela mokraćnog sustava (dominantno kanalnog sustava bubrega i mokraćovoda). Aristolohična kiselina, odnosno DNA njezinih adukata, je dokazana u zahvaćenom tkivu bubrega, odnosno urotela, a također su zamijećene i mutacije tumor-supresorskog gena $\mathrm{p} 53^{2}$. Zahvaćanje stanica proksimalnog tubula dovodi do intersticijske fibroze, kronične bubrežne insuficijencije i potrebe za nadomjesnim liječenjem bubrežne funkcije. Zahvaćenost urotela vodi razvoju karcinoma prijelaznoga epitela, stoga je EN povezan i s visokim rizikom razvoja karcinoma prijelaznog epitela gornjeg dijela mokraćnog sustava (UTUC od engl. upper tract urothelial carcinoma $)^{1,3}$. Prikazat ćemo pacijenticu s endemskom nefropatijom, liječenu na Klinici za urologiju Kliničkog bolničkog centra Rijeka, koja je nakon uspješne transplantacije bubrega razvila panurotelijalni karcinom.

\section{PRIKAZ SLUČAJA}

Pacijentici, tada 76-godišnjakinji, 2013. godine učinjena je kadaverična transplantacija bubrega. Rođena je u mjestu Stupnički Kuti, u endemskom području za EN, pokraj rijeke Save i Slavonskog Broda. Ondje je živjela do svoje 21. godine života, kada se preselila u Rijeku. Majka i brat su također bili bubrežni pacijenti (kasnije i transplantirani). Pacijentica se više od desetljeća kontrolirala kod nefrologa zbog poremećaja bubrežne funkcije i mikroalbuminurije. S obzirom na podrijetlo i obiteljsku anamnezu postavljena joj je dijagnoza endemske nefropatije. Godinu dana prije transplantacije bubrežna insuficijencija progredirala je $u$ terminalni stadij te je nakon preddijalizne edukacije odabrala peritonejsku dijalizu kao metodu nadomjesnog liječenja. Tijekom preddijalizne edukacije pokrenuta je i obrada za transplantaci-

Endemska nefropatija je kronična tubulointersticijska bubrežna bolest vezana uz specifično endemsko područje, koja dovodi do kroničnog bubrežnog zatajenja. Najvažnija obilježja ove bolesti jesu učestalo javljanje unutar obitelji, dugotrajno asimptomatsko razdoblje i visoka učestalost karcinoma prijelaznog epitela gornjeg dijela mokraćnog sustava.

ju bubrega. Početkom prosinca 2012. godine započela je s peritonejskom dijalizom. Tijekom navedenog razdoblja dovršena je i obrada za uvrštenje na listu čekanja za transplantaciju bubrega od umrle osobe. S obzirom na osnovnu bolest, učinjen joj je ultrazvuk urotrakta, cistoskopija kao i citološka analiza urina koji su bili urednog nalaza. Biopsija bubrega nije učinjena.

U rujnu 2013. godine učinjena joj je kadaverična transplantacija bubrega. Darivatelj organa bila je 65-godišnja žena koja je preminula zbog infarkta miokarda. Unutar sustava HLA (engl. Human Leukocyte Antigens) bile su dvije podudarnosti od mogućih šest (A, B i DR lokus) uz negativnu prijetransplantacijsku križnu reakciju. Neposredno pred operaciju dobila je indukcijsku terapiju (basiliximab). Desni bubreg darivatelja je usađen u lijevu ilijačnu jamu primatelja standardnom tehnikom. Terminolateralnom anastomozom spojene su bubrežna arterija i vena presatka s vanjskim ilijačnim žilama primatelja. Mokraćni mjehur je bio izuzetno tanke stijenke te se prilikom prepariranja široko otvorio, a inspekcijom na vidljivoj sluznici nisu primijećene patološke promjene. Zbog tanke stijenke mjehura nije učinjena standardna ekstravezikalna ureterovezikalna anasto- 
moza po Röhlu već po metodi Taguchi uz zaštitnu endoprotezu (JJ). Operacija je trajala 205 minuta, a hladna ishemija je bila 18 sati. Postoperacijski tijek je bio uredan uz potpuni oporavak bubrežne funkcije. Sedmog postoperacijskog dana odstranjen joj je dren, a četrnaestog dana urinarni kateter. Kontrolni ultrazvučni pregled pokazao je da je transplantat urednog sonografskog prikaza, bez hidronefroze i bez perirenalnih kolekcija. U pacijentice je učinjena scintigrafija transplantiranog bubrega, kao i citološka analiza urina, koji su bili

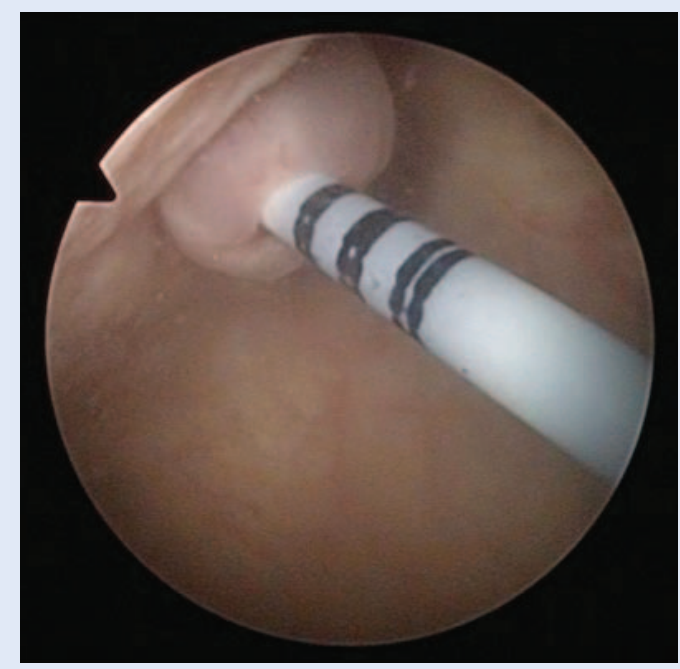

Slika 1. Cistoskopski prikaz mokraćnoga mjehura. Vidljiva JJ endoproteza u ektopičnom ureteralnom ušću nakon učinjene transplantacije bubrega.

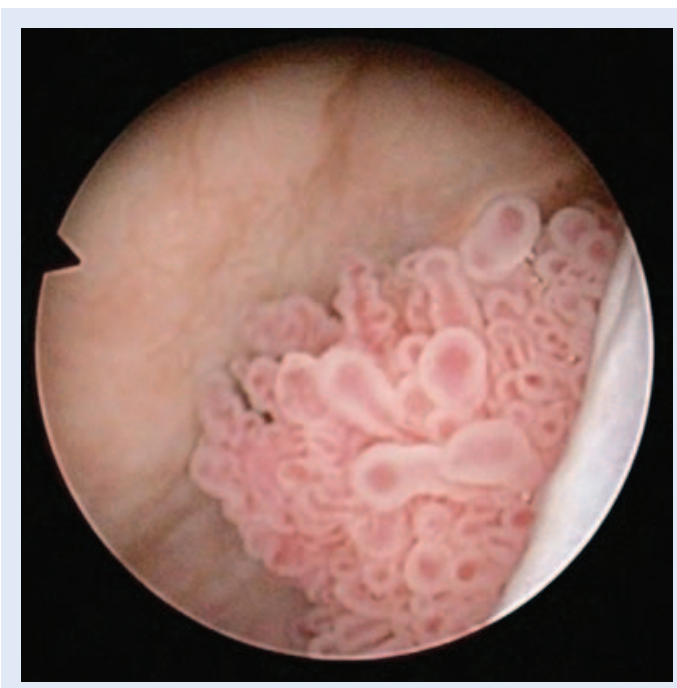

Slika 2. Cistoskopski prikaz tumora mokraćnoga mjehura. Slučajni nalaz papilarnog tumora na prednjoj stijenci mokraćnoga mjehura otkriven prilikom postavljanja JJ endoproteze. urednog nalaza. Otpuštena je na kućno liječenje uz imunosupresivnu terapiju: takrolimus, mikofenolat-mofetil i kortikosteroid. Mjesec dana po operaciji pacijentici je odstranjena ureteralna endoproteza.

U prosincu 2013. godine zbog ponavljajuće hidronefroze I stupnja presatka i umjereno povišenih parametara bubrežne funkcije postavljena joj je double J endoproteza u transplantirani bubreg (slika 1). Prilikom cistoskopije je na prednjoj stijenci mokraćnog mjehura uočen manji papilarni tumor veličine $5 \mathrm{~mm}$ (slika 2). Učinjena je hladna biopsija i elektrokoagulacija tumora. Kontrolnim ultrazvučnim pregledom prikazao se transplantirani bubreg bez hidronefroze uz vidljiv kraj petlje endoproteze u pijelonu, čiji se položaj potvrdio i rendgenskom snimkom urotrakta. Histološki nalaz bioptiranog papilarnog tumora odgovarao je karcinomu prijelaznoga epitela visokoga stupnja. $\mathrm{U}$ imunosupresivnu terapiju uveden je everolimus. U siječnju 2014. godine učinjena je cistoskopija i izvađena JJ endoproteza, no bez znakova za recidiv tumora. Nakon tri mjeseca napravljena je kontrolna cistoskopija te su na prednjoj stijenci mokraćnog mjehura uočena tri papilarna tumora veličine do $1 \mathrm{~cm}$. Učinjena je transuretralna resekcija recidivnog tumora mokraćnog mjehura te je uzet ispirak urina iz oba bubrega za citološku analizu. Patohistološki nalaz je odgovarao karcinomu prijelaznog epitela mokraćnog mjehura visokog stupnja (pT1). U citološkom nalazu ispirka urina iz oba bubrega pronađene su maligne stanice. Zbog osnovne bubrežne bolesti i pozitivnog citološkog nalaza urina posumnjalo se na karcinom prijelaznog epitela gornjeg dijela mokraćnog sustava te je u kolovozu 2014. godine učinjena eksplorativna bilateralna ureterorenoskopija (URS), pri čemu su nađeni tumori obostrano u nativnom ureteru i pijelonu. $U$ dva akta učinjena je obostrana nefroureterektomija te su obostrano pronađeni multicentrični tumori prijelaznoga epitela pijelona i uretera (pT2). Na kontrolnoj cistoskopiji nakon obostrane nefroureterektomije ponovno je zapažen recidiv tumora mokraćnog mjehura. U pacijentice su učinjene još dodatne četiri transuretralne resekcije tumora mokraćnoga mjehura zbog recidivnih, mutiplih, papilarnih, površinskih tumora mjehura, a patohistološki na- 
laz je uvijek govorio u prilog površinskog karcinoma urotela. Dodatnom obradom pronađene su i jetrene metastaze. Pacijentica je prikazana na uro-onkološkom konziliju, ali se zbog uznapredovale bolesti i slabijeg općeg stanja odustalo od kemoterapije. Unatoč izmjeni imunosupresivne terapije i provedenog kirurškog liječenja, a zbog uznapredovale maligne bolesti, pacijentica je preminula u travnju 2016. godine s normalno funkcionirajućim presatkom.

\section{RASPRAVA}

Endemsku nefropatiju su, krajem 50 -ih godina prošlog stoljeća, prvi opisali Tanchev i suradnici analizirajući učestalu pojavu bubrežnih bolesti u okolici grada Vratza u Bugarskoj ${ }^{4}$ Prvi opis ove bolesti u Hrvatskoj su objavili Pichler i suradnici, a u narodu se ova bolest zvala i kobaška bolest, budući da je prvo zahvaćeno mjesto bilo Slavonski Kobaš 5 . Kliničku sliku ove bolesti obilježava dugotrajan asimptomatski tijek, a izostanak specifičnih dijagnostičkih i kliničkih znakova onemogućava pravovremenu dijagnozu. Simptomi i znakovi bubrežne insuficijencije kroničnog tipa javljaju se tek u kasnijoj, uznapredovaloj fazi bolesti, u kojoj nastupa ireverzibilno oštećenje

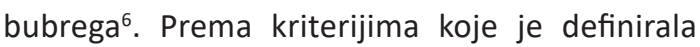
međunarodna Radna grupa za endemsku nefropatiju (inicijalni sastanak održan na Braču 2008. godine uz dodatni u Skopju 2012. godine) jedan od glavnih čimbenika rizika za razvoj bolesti jest pozitivna obiteljska anamneza i boravak u endemskom području dulji od 20 godina ${ }^{7}$. $U$ naše su pacijentice oba kriterija bila ispunjena, budući da su joj majka i brat bili transplantirani bubrežni pacijenti, a značajan dio života provela je u Brodsko-posavskoj županiji.

Posebno obilježje endemske nefropatije su urotelijalni karcinomi koji predstavljaju malignu transformaciju prijelaznog epitela mokraćnog sustava. Općenito, urotelijalni karcinomi mogu se podijeliti na karcinome koji zahvaćaju donji dio mokraćnog sustava (mokraćni mjehur i mokraćna cijev) i one koji zahvaćaju gornji dio mokraćnog sustava (mokraćovodi i kanalni sustav bubrega). Urotelijalni karcinomi donjeg dijela mokraćnog sustava predstavljaju 90 - $95 \%$ svih urotelijalnih karcinoma, a njih 15 - 25 \% su invazivni tumori. Karcino- mi prijelaznog epitela gornjeg dijela mokraćnog sustava (UTUC) čine $5-10 \%$ svih urotelijalnih karcinoma, a u trenutku postavljanja dijagnoze njih $60 \%$ je invazivno ${ }^{8-10}$.

Specifičnost EN-a je značajno povećan rizik za razvoj UTUC-a7,11. Istraživanja u Republici Hrvatskoj pokazala su kako je i do 55 puta veći specifični mortalitet od navedenog karcinoma $u$ endemskim područjima nego u ostalim dijelovima $\mathrm{Hr}$ vatske $^{12,13}$. Zbog toga sve pacijente $\mathrm{s}$ EN-om treba redovito kontrolirati kako bi se UTUC otkrio u što

Karcinomi prijelaznog epitela gornjeg dijela mokraćnog sustava izrazito su rijetki zloćudni tumori. Posebno ugrožena skupina pacijenata za razvoj ovog karcinoma su transplantirani pacijenti s endemskom nefropatijom. U njih je vrlo važna prijetransplantacijska priprema koja može uključivati i obostranu nefroureterektomiju.

ranijoj fazi. U pacijenata $s$ EN-om koji imaju uznapredovali stadij bubrežne insuficijencije ( $\geq 3 \mathrm{~A}$ ili su na hemodijalizi) preporučuje se svakih 6 mjeseci učiniti citološki pregled urina i ultrazvuk urotrakta ili neku drugu slikovnu dijagnostičku pretragu. U pacijenata koji su prethodno imali UTUC, tumor mjehura ili imaju hematuriju, preporučuje se pregled svaka tri mjeseca, a u slučaju hematurije svakako je potrebna i cistoskopija. Kod visoke sumnje na UTUC može se učiniti i CT urografija ili eksplorativna ureterorenoskopija. U pacijenata koji su transplantirani ili u onih koji su na dijalizi preporučuje se učiniti cistoskopiju svakih 6 mjeseci uz citološku pretragu urina7.

Liječenje UTUC-a kod pacijenata s EN-om je standardno kao i kod opće populacije te uključuje nefroureterektomiju zahvaćene strane. S obzirom na to da se učestalost karcinoma mokraćnoga mjehura ne razlikuje od opće populacije, cistektomija nije potrebna osim ako se ne radi o invazivnom karcinomu, međutim, ako se u tkivu mokraćnog mjehura pronađu DNA adukti aristolohične kiseline, preporučuje se cistektomija?. Smatra se kako oboljeli od EN-a u kojih je učinjena transplantacija bubrega predstavljaju posebno ranjivu skupinu za razvoj UTUC-a, najvjerojatnije kao posljedicu promijenjenog imunološkog odgovora zbog uzimanja imunosupresivne terapije ${ }^{14-17}$. 
Pacijenti s EN-om u kojih je učinjena transplantacija bubrega imaju značajno veću učestalost UTUC-a ${ }^{7,16,17}$. Studija iz našeg transplantacijskog centra pokazala je kako je u 3 od 6 pacijenata (50 \%) s EN-om došlo do razvoja UTUC-a nakon transplantacije bubrega. $U$ dvoje pacijenata UTUC je doveo do metastatske bolesti uz letalni ishod ${ }^{17}$. U studiji Bašić-Jukić i sur. UTUC je dijagnosticiran u 3/9 (33,3 \%) transplantiranih pacijenata s EN-om, a uzrok smrti je u dvojice pacijenata bila metastatska bolest ${ }^{16}$. S obzirom na agresivnost ove bolesti u obzir dolazi učiniti obostranu nefroureterektomiju prije ili nakon transplantacije ${ }^{7}$. Radna grupa preporučuje učiniti bilateralnu nefroureterektomiju u svih primatelja $s$ EN-om mlađih od 65 godina. $U$ osoba starijih od 65 godina bilateralna nefroureterektomija treba se učiniti ako u anamnezi postoji UTUC ili tumor mjehura, odnosno ako postoji obiteljska opterećenost s UTUC-om ${ }^{7}$. U pacijenata koji odbijaju bilateralnu nefroureterektomiju prije transplantacije bubrega neophodno je njihovo kontinuirano praćenje. Također se preporučuje u imunosupresivnoj terapiji koristiti mTOR inhibitore ${ }^{7}$. U transplantiranih pacijenata s EN-om nužno je njihovo redovito praćenje uz redovite ultrazvučne preglede bubrežnog presatka, mokraćnog mjehura, citološku analizu urina i cistoskopiju (pacijenti u kojih je učinjena obostrana nefroureterektomija), a dodatno se može učiniti i ultrazvuk nativnih bubrega, CT urografija i obostrana eksplorativna ureterorenoskopija (pacijenti u kojih nije učinjena bilateralna nefroureterektomija).

Kod živog darivatelja koji potječe iz endemskog područja potrebno je, uz standardne pretrage, učiniti i one dodatne. Ako je darivatelj živio u endemskome području dulje od 15 godina, preporučeno je učiniti biopsiju bubrega kako bi se isključio EN i/ili dokazalo odsustvo DNA adukata aristolohične kiseline. Pronalazak samo jednog od ovih dvaju čimbenika isključuje mogućnost darivateljstva?.

$U$ naše se pacijentice $s$ EN-om razvila panurotelijalna bolest. Ovakav oblik bolesti se u praksi ne susreće često, ali ovi pacijenti predstavljaju pravi izazov za kliničara. Temelj liječenja čini obostrana nefroureterektomija s cistektomijom, međutim, riječ je o izuzetno opsežnom zahvatu sa značaj- nim morbiditetom i mortalitetom. Ujedno u transplantiranih pacijenata treba riješiti i pitanje derivacije urina (najčešće stvaranjem urinarne derivacije korištenjem ileuma ili ureterokutanostomije). S obzirom na to kako su bubrezi ionako nefunkcionalni, njihovo odstranjenje, zajedno $s$ ureterima, ne narušava dodatno zdravlje, no pitanje cistektomije ima značajne kliničke posljedice u transplantiranih pacijenata ili onih koji su kandidati za nju. Odluku o tome treba li učiniti cistektomiju može olakšati resekcija tumora mokraćnog mjehura kao i nasumične biopsije sluznice mjehura. Ako se u patohistološkom materijalu pronađu DNA adukti aristolohične kiseline, postoji vrlo velika vjerojatnost panurotelijalnog karcinoma te se preporučuje cistektomija.

\section{ZAKLJUČAK}

EN nije česta bolest, ali ima svoje specifičnosti, ponajprije u vidu razvoja UTUC-a, koje mogu dovesti do značajnog morbiditeta i mortaliteta pacijenata. Transplantirani pacijenti s EN-om zahtijevaju doživotno praćenje radi pravovremenog otkrivanja UTUC-a, a u slučaju razvoja panurotelijalnog karcinoma neophodno je radikalno kirurško liječenje.

Izjava o sukobu interesa: Autori izjavljuju da ne postoji sukob interesa.

\section{LITERATURA}

1. Jelaković B, Dika Ž, Karanović S, Vuković-Lela I. Endemska nefropatija u Hrvatskoj. Lijec Vjesn 2015;137:100-8.

2. Jelaković B, Karanović $S$, Vuković-Lela I, Miller F, Edwards $\mathrm{KL}$, Nikolić $\mathrm{J}$ et al. Aristolactam-DNA adducts are a biomarker of enviromental exposure to aristolochic acid. Kidney Int 2012;81:559-67.

3. Ivić M. Etiology of endemic nephropathy. Lijec Vjes 1969; 91:1273-81.

4. Tanchev Y, Evstatiev Z, Dorossiev D, Pencheva J, Tzvetkova $G$. Studies on the nephritides in the District of Vratza. Savremena Medicina 1956;7:14-29.

5. Pichler $O$, Bobinac E, Miljuš B, Sindik A. O učestaloj pojavi bubrežnih oboljenja u okolici Slavonskog Broda. Lijec Vjesn 1959;81:295-306.

6. Stefanović V, Cukuranović R, Miljković S, Marinković D, Toncheva D. Fifty years of Balkan endemic nephropathy: challenges of study using epidemiological method. Ren Fail 2009;31:409-18.

7. Jelaković B, Nikolić J, Radovanović Z, Nortier J, Cosyns JP, Grollman AP et al. Consensus statement on screening, diagnosis, classification and treatment of endemic (Balkan) nephropathy. Nephrol Dial Transplant 2014;29: 2020-7. 
8. Tyler A. Urothelial cancers: ureter, renal pelvis, and bladder. Semin Oncol Nurs 2012;28:154-62.

9. Roupret M, Babjuk M, Comperat E, Zigeuner R, Sylvester $\mathrm{RJ}$, Burger $\mathrm{M}$ et al. European association of urology guidelines on upper urinary tract urothelial carcinoma: 2017 update. Eur Urol 2018;73:111-22.

10. Munoz JJ, Ellison LM. Upper tract urothelial neoplasms: incidence and survival during the last 2 decades. J Urol 2000;164:1523-5.

11. Petronić VJ, Bukurov NS, Djokić MR, Milenković DZ, Vuksanović AM, Avramović AD et al. Balkan endemic nephropathy and papillary transitional cell tumors of the renal pelvis and ureters. Kidney Int Suppl 1991;34:S77-9.

12. Miletić-Medved M, Domijan AM, Peraica M. Recent data on endemic nephropathy and related urothelial tumors in Croatia. Wien Klin Wochenschr 2005;117:604-9.
13. Medunjanin D, Sonicki Z, Vena JE, Cvitković A, Wagner Robb. Geographic distribution and risk of upper urothelial carcinomas in Croatia, 2001-2011. BMC Cancer 2019;19:950.

14. Penn I. Malignancies associated with renal transplantation. Urology 1977;10:57-63.

15. Briggs JD. Causes of death after renal transplantation. Nephrol Dial Transplant 2001;16:1545-9.

16. Bašić-Jukić $N$, Hršak-Puljić I, Kes P, Bubić-Filipi L,Pasini J, Hudolin $\mathrm{T}$ et al. Renal transplantation in patients with Balkan endemic nephropathy. Transplant Proc 2007;39: 1432-5.

17. Živčić-Ćosić $S$, Gržetić $M$, Valenčić $M$, Oguić $R$, Maričić $A$, Đorđević $\mathrm{G}$ et al. Urothelial cancer in patients with endemic balkan nephropathy (EN) after renal transplantation. Ren Fail 2007;29:861-5. 